\title{
MODELING PARTICIPANT TOWARD SELF-CARE DEFICIT ON SCHIZOPHRENIC CLIENTS
}

\author{
Ah Yusuf*, Hanik Endang Nihayati*, Krisna Eka Kurniawan** \\ *Faculty of Nursing, Universitas Airlangga \\ **Nurse Practitioner, Mental Hospital Dr. Radjiman Wediodiningrat Lawang \\ Email: ah-yusuf@fkp.unair.ac.id
}

\begin{abstract}
Introduction: Schizophrenia is a disease which affects the brain, causing impaired perception, thought, emotion, movement, and behavior, such as self-care deficit. Self-care deficit is an impaired ability to bathing, dressing, eating and toileting. Modeling participant is a technique required to address the problem of self-care deficit where clients are taught and trained to meet the needs of self-care. The purpose of this study was to analyze the influence of participants modeling on self-care ability in schizophrenic clients with self-care deficit. Method: This study used quasi-experimental design. Sampling was carried out with total sampling to all affordable population comprising 20 respondents in Dr. Radjiman Wediodiningrat Mental Hospital, Lawang. This study analyzed by Wilcoxon Signed Rank Test and Mann-Whitney Test with a significance level of $\mathrm{p} \leq 0.05$. Result: The results showed the influence of participants modeling on self-care ability in schizophrenic clients with self-care deficit. Wilcoxon Signed Rank Test in treatment group showed $p=0.005$ and control group showed $p=$ 0,206. Mann-Whitney Test showed $\mathrm{p}=0.030$. Modeling participant improved self-care ability in schizophrenic clients with self-care deficit. Analysis: Modeling participant will improve cognitive, self-confidence and motivation of schizophrenic clients so that their ability to bathing, dressing, eating and toileting will increase. Discussion: Modeling participant can be applied as a technique to improve self-care ability in schizophrenic clients with self-care deficit. For further research can be explored further implementation of the modeling of participants in the group activity therapy.
\end{abstract}

Keywords: modeling participant, self-care, schizophrenia.

\section{INTRODUCTION}

Schizophrenia is a disease which affects brain, causing impaired perception, thought, emotion, movement, and behavior (Videbeck 2008). Symptoms of schizophrenia include delusions, hallucinations, affective flattening or blunt, poor of speaking or meaning, blocking, self-care deficit, low motivation, and selfwithdrawal from social (Sadock \& Sadock 2010). Schizophrenic client disorders such as behavior derangement, perceptive, cognitive disability will cause the client can't take care of himself adequately. The inability to care for himself will emergence of self-care deficit problem. Self-care deficit is a common problem in schizophrenic clients, both being treated at hospital and community. Direja (2011) states that the self-care deficit is an impaired ability to perform self-care activities (bathing, dressing, eating, toileting). Inability to perform self-care activities without intervention by the nurse, the schizophrenic client will get a higher risk of social isolation or low self-esteem. General nursing interventions addressing self-care deficit problems are taught and trained the client to meet the needs of self-care includes bathing, dressing, eating and drinking properly and also bowel or urinate correctly (Rochmawati et al. 2013). Those nursing actions are implemented through nursing care, but it still found a schizophrenic client with self-care disorder.

Schizophrenia affects approximately 24 million people worldwide (World Health Organization 2014). The prevalence of severe mental disorders (psychosis/schizophrenia) in Indonesia is 1.7 per mil. The prevalence of severe mental disorders in East Java was 2.2 per mil (Badan Penelitian dan Pengembangan Kesehatan Kementerian Kesehatan RI 2013). Base Health Research (Riskesdas) in 2013, the prevalence of people with mental emotional problem in population over 50 years old found approximately $6 \%$, or about 16 million people, People with severe mental disorders about 400 thousand and 57 thousand people with severe mental disorder have been deprived by the family (Kemenkes 2014). Schizophrenic client with social isolation about $72 \%$ and $64 \%$ experiencing decreased ability to take care themselves (eating, bathing and dressing) (Surtiningsrum 2011). The percentage of nursing problems by deficit self-care in February 2008 at Marzoeki Mahdi Hospital Bogor reaches $80 \%$ (Perendrawati 2008). Initial data has retrieved by researchers from Medical Record of Dr. Radjiman Wediodiningrat Mental Hospital Lawang, the data shown the schizophrenic client who was treated at 28 inpatient room in October 2014 were 567 clients, $70 \%$ were male, and $30 \%$ were female. 
Preliminary studies conducted by researchers at the Kenari room obtain data that 17 out of 41 clients or $41 \%$ of clients who were treated had self-care deficit, while in Kakak Tua room were $31 \%$. Nursing interventions for schizophrenic clients with self-care deficit in Kenari room Dr. Radjiman Wediodiningrat Mental Hospital Lawang is nursing care and behavioral therapy. Nursing care includes self-care teaching and motivating clients to perform self-care, but still found schizophrenic clients with impaired ability to take care of themselves.

Self-care deficit is a situation where experiencing barriers to perform self-care activities, such as bathing, changing clothes, eating and eliminating. Barriers/interference ability to take care of themselves at schizophrenic client caused by cognitive or perceptual disturbances (Wilkinson \& Ahern 2013). Several disturbance were experienced by the schizophrenic client such as behavior derangement, perceptive, cognitive disability and it will cause the client can't take care of themselves. Clients can be very preoccupation with delusions or hallucinations idea until they fail for carrying out daily activities (Videbeck 2008). If self-care deficit is not treated immediately, it will lead to some new problems and worsen. Teaching techniques required to improve self-care ability through demonstrations by the model. Ormrod (2009) states, as humans we have the ability to imitate others since we were born. A schizophrenic client experiencing cognitive, perceptive and behavior impairment, so it will be easier for them to improve self-care ability by mimicking models in modeling participants. According to Bandura in Ningsih \& Sutjiono (2011), modeling participants accelerate behavior changes level, attitudes facing of alarming stimuli.

Modeling technique was done by a therapist/nurse through demonstration to the client about what to do (Nasir \& Muhith 2011). Modeling technique has several kinds; live models, symbolic models, multi-model (dual characterizations), self-model, modeling participants (Junaedi \& Nursalim 2011). Modeling participants is a way to learn new behaviors through observation from a model, add information through cognitive processes to get output appropriate behavioral changes were modeled (Iswanti 2012). Iswanti Research (2012), shown differences in medication adherence in the intervention group who received behavior therapy of modeling participants, whereas the control group was no differences in medication adherence. Ningsih and Sutijono (2011) research concluded that modeling participant strategy influence improve students skill in class. This indicates that the participant modeling can be used as a therapy to improve the ability of the client. One of nursing intervention in self-care deficit consists of knowledge and ability improvement to perform self-care (Wilkinson \& Ahern 2013). Main element of modeling participants consist of rational, modeling, guided participation and strengthening is needed as a technique to implementing the nursing interventions. Client knowledge can be enhanced through rational, clients are taught how to care themselves through modeling and guided participation. Bandura states that learning can be obtained through direct experience, indirectly by observing the behavior of others and their consequences (Corey 2009). Lastly, clients will be motivated to perform self-care activities through strengthening elements. Participants are expected to change behavior from maladaptive become adaptive through modeling participant and increase self-care ability. Based on these, researchers want to know the influence of modeling participants in a schizophrenic client with self-care deficit in Dr. Radjiman Wediodiningrat Mental Hospital Lawang.

\section{METHOD}

This study analyzes the influence of modeling participants in a schizophrenic client with self-care deficit. The research design is Quasi-Experiment design. The affordable population in this study are 29 respondents of schizophrenic clients with self-care deficit in Kenari and Kakak Tua room at Dr. Radjiman Wediodiningrat Mental Hospital Lawang. The sampling technique in this study is nonprobability with total sampling technique. The sample consists of affordable population taken by inclusion and exclusion criteria were 20 respondents then divided into treatment group and control group. Independent variables in this study are modeling participants. The dependent variable is self-care ability.

Data was analyzed by Wilcoxon Signed Rank Test to compare client's self-care ability in a schizophrenic client with self-care deficits before and after modeling participants, 
significance level established $\mathrm{p}<0.05$. MannWhitney is used to determine differences in self-care ability of schizophrenic client with self-care deficit in treatment group and control group with significance level established $\mathrm{p}$ $<0.05$.

\section{RESULTS}

\section{Self care ability before modeling participant treatment}

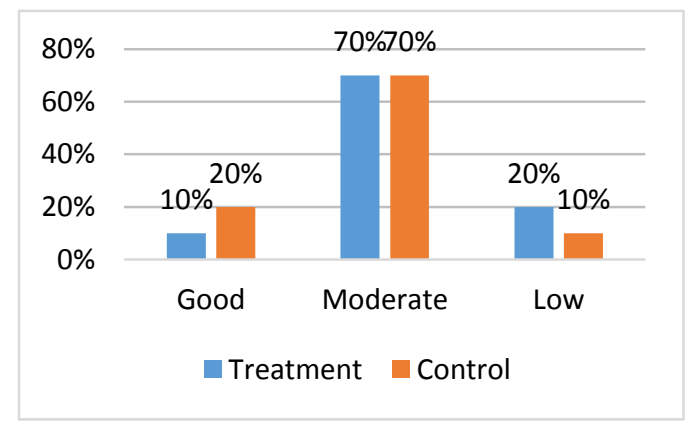

Figure 1 Self Care Ability Before Modeling Participants Treatment.

Figure 1 shows self-care ability of schizophrenic client with self-care deficit before modeling participants intervention, both in control group and treatment group was $70 \%$ in enough category. Although they can take care of themselves, respondents still need help in caring for their activities.

Majority bathing ability of respondents need help such as prepare necessary equipment (towels, soap, adequacy of water), watering all the body, rub whole body with soap thoroughly, showering water and rinse entire body until clean, and dry off with a towel. Some respondents independently have the ability to enter and out from the bathroom. This is because some equipment for bathing include towels are often lost or discarded by respondents or taken by other clients who are less cooperative. Respondents are just soaking and scrubbing front part of the body only, while the back and legs are not wetted and rubbed with soap. Some respondents did not bathe with soap and did not wear a towel after have bathed.

Respondent's self-care ability in dressing, need assistance while preparing necessary dressing equipment, gain or change clothes, choose appropriate clothes, cleaning whiskers, and retains appearance at a satisfactory level. Respondents tend to be assisted in dressing and rarely given an opportunity to do it independently. In eating ability of respondents require assistance in preparing equipment and food. The ability of respondent's bowels/urinate need help to go to the toilet, wipe after a bowel/urinate with clean water, and flush toilets cleanly and not smell. Many respondents are urinated no in the bathroom, not wipe and flush the toilet after a bowel /urinate. Respondents argued lazy to do so.

\section{Self-care ability after modeling participant treatment}

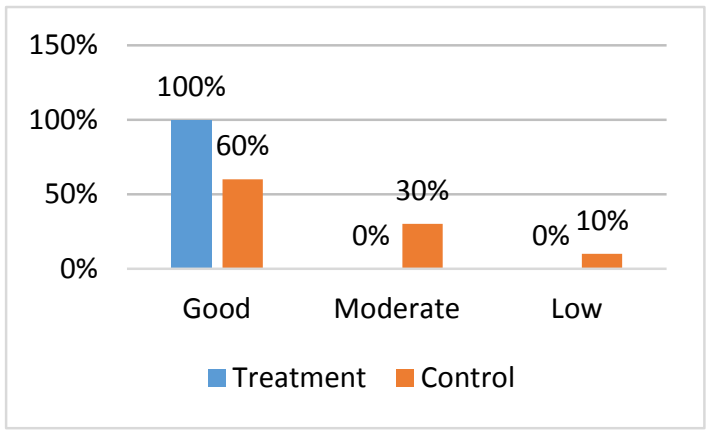

Figure 2 Self-care ability of respondents after Modeling participant treatment

Figure 2 shows that self-care ability of control group after given the treatment was $60 \%$ in good level. Whereas treatment group was $100 \%$.

\section{Modeling participant effect in self-care ability.}

Based on table 1 the results of Wilcoxon Signed Rank Test showed an increased selfcare ability in treatment group before and after modeling participant with $\mathrm{p}=0.005$ means $\mathrm{p}$ $<\alpha$, then $\mathrm{H} 1$ accepted which means modeling participant effect was significant to self-care ability. The different result obtained in control group amount $\mathrm{p}=0.206$ means $\mathrm{p}>\alpha>0.05$, then $\mathrm{H} 1$ rejected which means modeling participants effect was not significant to selfcare ability in the control group. Mann-Whitney Test results showed $\mathrm{p}=0.030$ means $\mathrm{p}<\alpha$ $<0.05$, thus self-care ability level after treatment shown significant differences between control and treatment group so it can conclude that modeling participant influence self-care ability in the schizophrenic client. 
Table 1 Self-care ability level before and after given modeling participant treatment in control and treatment group at Dr. Radjiman Wediodiningrat Mental Hospital Lawang

\begin{tabular}{|c|c|c|c|c|c|c|c|c|c|}
\hline \multirow{3}{*}{ No } & \multirow{3}{*}{ Criteria } & \multicolumn{4}{|c|}{ Treatment } & \multicolumn{4}{|c|}{ Treatment } \\
\hline & & \multicolumn{2}{|c|}{ Before } & \multicolumn{2}{|c|}{ Before } & \multicolumn{2}{|c|}{ Before } & \multicolumn{2}{|c|}{ After } \\
\hline & & $\Sigma$ & $\%$ & $\Sigma$ & $\%$ & $\Sigma$ & $\%$ & $\Sigma$ & $\%$ \\
\hline 1 & Good & 1 & 10 & 10 & 100 & 2 & 20 & 6 & 20 \\
\hline 2 & Moderate & 7 & 70 & 0 & 0 & 7 & 70 & 3 & 70 \\
\hline \multirow[t]{2}{*}{3} & Low & 2 & 20 & 0 & 0 & 1 & 10 & 1 & 10 \\
\hline & Total & 10 & 100 & 10 & 100 & 10 & 100 & 10 & 100 \\
\hline & \multirow{2}{*}{ Statistics } & \multicolumn{4}{|c|}{$\begin{array}{c}\mathrm{p}=0.005 \\
\text { Wilcoxon Signed Rank Test }\end{array}$} & \multicolumn{4}{|c|}{$\begin{array}{c}\mathrm{p}=0.206 \\
\text { Wilcoxon Signed Rank Test }\end{array}$} \\
\hline & & \multicolumn{8}{|c|}{$\begin{array}{c}\mathrm{p}=0.030 \\
\text { Mann-Whitney Test }\end{array}$} \\
\hline
\end{tabular}

\section{DISCUSSION}

Schizophrenia is a disease affecting brain causes strange and disturbing of perceptions, thoughts, emotions, movement, and behavior (Videbeck 2008). Symptoms of schizophrenia include delusions, hallucinations, affective flattening or blunt, poor speech or meaning, blocking, self-care deficit, lack of motivation and social withdrawal (Sadock \& Sadock 2010). Clients can be very preoccupation with delusions or hallucinations and failed to carry out basic activities in daily life (Videbeck, 2008). Schizophrenic disturbance such as behavior disorders, perceptual, cognitive disability will cause client can not take care of himself adequately. It can be seen from negative and positive symptoms. Clients did not care about individual, events, and activities. The client was not happy in joining life and activity, including self-care activities. Clients also experience loss of motivation and did not have the willing. Inability to take care of himself will emergence of self-care deficit problem.

Respondents with self-care in enough and less level were $41 \%$ aged $36-45$ years. According to Mariner level of self-care ability of person affected by age, stage of development, life experiences, socio-cultural background, health, and available resources (Andayani 2012). States age is related to experience in dealing various kinds of stressors, the ability to use support resources and skills in coping mechanisms (Stuart \& Laraia 2005; Perendrawati 2008). Stressor encountered in adulthood age is more complex than other age ranges, but adulthood is better selecting their basic needs and make a decision or take action which can improve their condition.
The education level of all respondents with less self-care ability are elementary school level. Factors affecting hygiene is knowledge. Personal hygiene knowledge is very important because a good knowledge can improve health level (Potter 2006; Kozier 2010). Clients also need motivation to maintain self-care. Person with higher education will get more knowledge about self-care so the motivation to care for themselves higher. Stuart \& Laraia (2005), stating that education becomes a benchmark of client's ability to interact effectively. Education affects client's ability to make decisions, utilize surrounding information, receive feedback and skills, and motivation to solve problem itself.

Respondents with enough and less selfcare ability in this study $82 \%$ were not working. Townsend (2005) in Parendrawati (2008) suggest that low socioeconomic is one of the social factors lead to high rates of mental disorders including schizophrenia. Work problems related to poverty, inadequate facilities, inadequate need of food, and housing, low health care quality of family members will trigger to limited coping on stressful situations. Respondents were not working have economic problems or low economic status. Economic problem was leading risk of developing schizophrenia. Economic conditions also affect to the fulfillment of daily needs, including needs their care.

All respondents with less self-care ability level were unmarried status. Dantas et. al. (2011) suggest that the incidence of schizophrenia is most occurs in not married status. The family role is very important to help and to support of client's self-care, so clients with not married status possible get the support from family to resolve their health problems.

Most respondent amounts $76 \%$ with enough, and less self-care ability level were 1-2 
times treated. Research of Andayani (2012) concluded that there is a significant correlation between frequency of respondents treated and self-care ability. Stuart and Laraia (2005) states that timing and duration of schizophrenic client exposure by stressor impact in the independence of self-care. A new schizophrenic client while first time exposing stressor require intensive efforts as primary prevention. Respondents with 1-2 times treated require intensive effort involving backup sources which owned by individuals, preventing self-care deficit becomes more difficult to overcome.

Respondents with enough and less selfcare ability level as many $82 \%$ are schizophrenia hebephrenic clients. Schizophrenia hebephrenic characteristic is irresponsible and unpredictability behavior, mannerism, tendency to be alone, hollow and empty feeling. Affective, encouragement impulse, and thought processes disorders prominent (Amin 2009). These symptoms will influence to client's self-care ability.

As many as $66 \%$ of respondents with less self-care ability receive combination therapy of typical and atypical antipsychotics. Typical antipsychotic overcomes positive signs of schizophrenia such as delusions, hallucinations, thought disorder, and other psychotic symptoms, but does not have a visible effect on negative signs. Atypical antipsychotics can reduce psychotic symptoms and useful to reduce negative symptoms such as not having the wish and motivation, social withdrawal and anhedonia (Videbeck, 2008). Schizophrenia handling is not only by psychopharmacy but also by nursing care. The goal of nursing care in self-care deficit client is improving client's knowledge and self-care ability.

The majority of client's self-care ability before given modeling participant treatment are enough level and adequate enough to take care of them, but should be helped and motivated by the nurse. This is due to client's condition who are still experiencing positive and negative symptoms of schizophrenia such as hallucinations, fragmented thoughts or ideas, careless feeling of people, activities, events, tendency to be very little speaking or poor meaning, unenjoyment living, activities, or relationships, loss of motivation to act or perform the tasks, lack of desire, ambition or motivation, dull or limited circumstances emotional feeling, social withdrawal.
All respondents of treatment group after modeling participant treatment has increased to be a good level of self-care ability. The age range respondents of treatment group are 18-55 years or adulthood. According to Siagian (1995) in Parendrawati (2008), the older person related to technical maturity, psychological maturity which shows the soul maturity, it means more wisdom, able to think rationally, control emotions and considerate of others. Respondent age affects to decision-making ability and take action for self-care improvement.

As many as $90 \%$ of respondents in the treatment group with good self-care ability ever get one time of care frequency. Stuart and Laraia (2005) states that timing and duration of stressor exposure influence the achievement of self-care independent in schizophrenic clients. A new schizophrenic client when first time exposed stressor requires intensive efforts as primary prevention. Modeling participant is one of intensive efforts to prevent self-care deficit problems from becoming more complex. The treatment group was trained intensively to take care for themselves as bathing, dressing, eating, and bowel/urinate and trained to practice these capabilities. Self-care ability of control group in enough and less level have 2-3 times treated frequency and unmarried status. This indicates the client tendency to relapse due to lack of family support. Unmarried respondents lived with their parents, but the case is the parents too old, so an intensive effort to overcome self-care deficit problems at home are less than optimal.

As many as $70 \%$ of respondents in the treatment group with good self-care ability have elementary school education level. Ajzen and Fishbein (1980) in Parendrawati (2008) suggests the 'theory of reasoned' which cognitive process is people basis to decide or take appropriate behavior, systematically using nearby available information. The nurse duties as an educator are providing self-care knowledge on the schizophrenic client. In this study, respondents were taught how to take care of themselves well so that respondent can improve their self-care ability.

Self-care ability in treatment group increases significantly at $20 \%$ respondents, which previously in less ability level to be good ability level. Type of drugs taken by respondents is typical and atypical combination therapy. Typical antipsychotic overcomes positive signs of schizophrenia such as 
delusions, hallucinations, thought disorder, and other psychotic symptoms, but does not have a visible effect on negative signs. Atypical antipsychotics can reduce psychotic and negative symptoms such as low motivation, social withdrawal, and anhedonia (Littrell \& Littrell, 1998, in Videbeck, 2008). The main goal of combination therapy is improving the effectiveness of antipsychosis and treatment outcome in resistant patients, strengthen antipsychosis potential effect, reducing the risk of side effects in certain combinations (Revenger 2010). Giving antipsychotics may reduce negative symptoms and positive symptoms, moreover support a better understanding of modeling participants.

In the control group are found 10\% respondents who experience decreased self-care ability. These respondents get typical antipsychotic. Typical antipsychotic overcomes positive signs of schizophrenia such as delusions, hallucinations, thought disorder, and other psychotic symptoms, but does not have a visible effect on the negative signs (Littrell \& Littrell, 1998, in Videbeck, 2008). Atypical antipsychotics are better in improving the performance of client function than typical antipsychotics because it affects larger negative symptom improvement (Revenger, 2010). Antipsychotic treatment affects schizophrenia symptoms, so it will influence respondents to understand the modeling participants.

In general, self-care ability of the treatment group and the control group had increased. It because both treatment group and control group respondents get nursing care and psychopharmacy therapy. Increasing self-care ability in the control group was not significant compared treatment group.

Modeling participants in the treatment group were given two times in meeting for each topic as bathing, dressing, eating, and bowel/urinate. Every topic is given in a single day. Models in this study is schizophrenic clients with independent self-care ability and one same room with respondent. Researchers also conducted demonstrations to restrengthening of topics were taught. The main focus of nursing care in self-care deficit client consists of two things: increase client's selfcare knowledge and ability, and assist clients on their limitations and give caring which client can't do (Wilkinson \& Ahern 2013). Purwanto (1999) in Parendrawati (2008) characteristic of learning is the change in people who learn, changes appears from not capable to be able. Modeling participants is a technique used in the treatment group to improve knowledge and ability. Researchers the model who have similarity characteristics with respondents so can motivate treatment groups to perform selfcare independently, and changes in self-care ability became significantly.

Modeling participant implementation purpose improving cognitive, self-confident, and motivation through implementing basic components of modeling participant such rational, modeling, guided participation and successful experience/reinforcement. Modeling participants as techniques used to form a new behavior, improve skills and minimize avoidable behavior. In this study, new behaviors and skills which improved is the selfcare ability (Iswanti 2012). Modeling participants also help clients performing a new behavior which obtains through appropriate way and time (Junaedi \& Nursalim 2011). Researchers are applying modeling participants to change the maladaptive behavior of respondents to be more adaptive.

Modeling participants consist of four topics; bathing, dressing, eating, toileting. One topic is given in one day, and every topic is repeated twice. In practice, researchers explain the benefits of proper self-care (bathing, dressing, eating, and toileting) also related tools which needed. It makes respondents get a better understand about the importance of self-care. Furthermore, Independent schizophrenia model demonstrates self-care ability and respondent are giving attention. Researchers also demonstrate self-care ability again as reinforcement. The model who has to resemble character with respondent increase respondent motivation. These explanation and demonstration improve respondent-cognitive ability as knowing benefits and proper self-care manner.

Respondent is practicing self-care ability such as bathing, dressing, eating, bowel/urinate guided by researchers. Researchers also give positive feedback when respondents successfully practice self-care ability properly. Some respondents get difficulties when practicing self-care ability, but researchers continue to guide and motivate them by the state that model which respondent friends can do. It increases respondents self-confidence and motivation to try again. 
Increased self-care ability in treatment groups after given modeling participant was appropriated with Iswanti study (2012), which indicates differences adherence medication in the treatment group who received behavior therapy as modeling participants, whereas no differences in the control group. Research of Ningsih \& Sutjiono (2011) concluded modeling participant strategy increase student opinion ability in class.

Bandura (1969) in Corey (2009), states that learning can be obtained through direct experience, also can be obtained indirectly by observing other person behavior and consequences. There are two types of learning through observation, first learning through observation can be occurred by other people circumstances/conditions. Second; learning through imitate observation by model behavior (Boeis 2007; Winarto 2011). Respondents are schizophrenic clients with cognitive and perceptions disorder, so it will be easier for respondents to learn by watching and imitating. In modeling participants, respondents learn to observe model behavior who schizophrenic client with independent self-care performance.

The most efficient model was using the therapist as a model, but bigger advantage gained when use model who similar with the client (Ningsih \& Sutjiono 2011; Junaedi \& Nursalim 2011). The using of collaborative models by researchers and schizophrenic client give greater advantage such motivation and confidence, respondents prefer imitate their friends whose schizophrenic in the same room. In this research, there were two models who have gone home before the research end. These improve respondent motivation indirectly, motivation to improve their self-care ability because if they have independence as a model then will go home quickly.

Implementation of modeling participants affects self-care ability through the learning process. Gibson stated that ability is something learned, allows a person to do something as well, both in intellectually and physically (Syarifuddin 2012). Respondents were taught self-care as well. Thus self-care ability both physically and cognitively were increased.

Modeling participants are one form of modeling which the key element in modeling process (Winarto 2011). While according to Bastable (2002) modeling participants is attention, recall (retention), reproduction of motion (reproduction), and motivation.
Attention means before imitating the model, respondent should pay attention or observe model behavior to learn. Recall (retention) is the ability to retain information is essential for the learning process. Clients must record this event in their memory. Reproduction of motion (reproduction) means after client knows and learn a behavior, clients can show their ability or produce which stored in the form of behavior. Mental exercise, direct application, and corrective feedback reinforce this behavior imitation. Motivation; motivation is important as client's driving to continue doing something. Vicarious reinforcement and punishment influence this process. Learning process in modeling participants improves self-care ability in the treatment group.

\section{CONCLUSION}

There are significant differences of respondent self-care ability in treatment group before and after given modeling participants.

Modeling participants can be used as supporting therapy to improve self-care ability in a schizophrenic client with self-care deficit problem.

\section{REFERENCES}

Amin, M., 2009. Peran Daerah Tempat Tinggal Terhadap Kejadian Penyakit Skizofrenia Pada Penderita Gangguan Jiwa Yang Dirawat Inap Di Rumah Sakit Dr Ernaldi Bahar Provinsi Sumatera Selatan Tahun 2007. Universitas Indonesia. Available at: http://lib.ui.ac.id/opac/ui/.

Andayani, S., 2012. Hubungan Karakteristik Klien Skizofrenia Dengan Tingkat Kemampuan Perawatan Diri di Ruang Rawat Inap Psikiatri Wanita Rumah Sakit Marzoeki Mahdi Bogor. Universitas Indonesia. Available at: http://lib.ui.ac.id/opac/ui/detail.jsp?id=203 11742\&lokasi=lokal.

Badan Penelitian dan Pengembangan Kesehatan Kementrian Kesehatan RI, 2013. Riset Kesehatan Dasar, Available at: www.litbang.depkes.go.id.

Bastable, S.B., 2002. Perawat Sebagai Pendidik: Prinsip-Prinsip Pengajaran dan Pembelajaran, Jakarta: EGC.

Boeis, K.K. et. al., 2007. Praktik keperawatan Profesional: Konsep \& Perspektif, Jakarta: EGC.

Corey, G., 2009. Teori dan Praktek Konseling 
dan Psikologi, Bandung: PT Refika Aditama.

Dantas et. al., 2011. Insight Controlled For Cognition in Deficit and Nondeficit Schizophrenia. Schizophrenia Reseach, 128, pp.124-126. Available at: http://www.elsevier.com/locate/schres.

Direja, A.H.S., 2011. Buku Ajar Asuhan Keperawatan Jiwa, Yogyakarta: Nuha Medika.

Iswanti, D.I., 2012. Pengaruh Terapi Perilaku Modeling Partisipan Terhadap Kepatuhan Minum Obat Pada Klien Penatalaksanaan Regimen Terapeutik Tidak Efektif di RSJD Dr. Amino Gondohutama Semarang. Universitas Indonesia. Available at: http://lib.ui.ac.id/opac/ui/detail.jsp?id=203 00661\&lokasi=lokal.

Junaedi, H. \& Nursalim, M., 2011. Penerapan Strategi Modeling Partisipan Untuk Meningkatkan Keterampilan Komunikasi antar Pribadi Siswa. Psikologi Pendidikan Dan Bimbingan, 12(1). Available at: http://ejournal.unesa.ac.id/index.php/ jurnal_ppb/article/view/5424/baca-artikel.

Kemenkes, 2014. Naskah Undang-Undang Kesehatan Jiwa Disetujui, Available at: http://www.depkes.go.id/article/view/201 407200002/naskah-undang-undangkesehatan-jiwa-disetujui.html.

Kozier, B., 2010. Buku Ajar Fundamental Keperawatan Konsep Proses dan Praktik, Jakarta: EGC.

Nasir, A. \& Muhith, A., 2011. Dasar-dasar Keperawatan Jiwa: Pengantar dan Teori, Jakarta: Salemba Medika.

Ningsih, P. \& Sutjiono, 2011. Penerapan Strategi Modeling Partisipan Untuk Meningkatkan Kemampuan Mengungkapkan Pendapat. Psikologi Pendidikan dan Bimbingan, 12. Available at:

http://ejournal.unesa.ac.id/index.php/jurna 1_ppb/article/view/5436/baca-artikel.

Ormrod, J.E., 2009. Psikologi Pendidikan Membantu Siswa Tumbuh dan Berkembang Jilid 2, Jakarta: Penerbit Erlangga.

Perendrawati, D.P., 2008. Pengaruh Terapi Token Ekonomi Pada Klien Defisit Perawatan Diri di Rumah Sakit Dr Marzuki Mahdi Bogor. Universitas Indonesia. Available at: http://lib.ui.ac.id/opac/ui/detail.jsp?id=126 565 \&lokasi=lokal.

Potter, P.A., 2006. Buku Ajar Fundamental Keperawatan: Konsep, Proses, dan Praktik, Jakarta: EGC.

Revenger, M.J., 2010. Perbandingan performa fungsi pasien skizofrenia yang mendapat terapi tunggal dengan terapi kombinasi antipsikotika di rumah sakit Cipto Mangunkusumo (Periode Desember 2011 - Mei 2012). Universitas Airlangga. Available at: http://lib.ui.ac.id/opac/ui/.

Rochmawati, D., Keliat, B. \& Wardani, I., 2013. Manajemen Kasus Spesialis Jiwa Defisit Perawatan Diri Pada Klien Gangguan Jiwa di RW 02 dan RW 12 Kelurahan Baranangsiang Kecamatan Bogor Timur. Jurnal keperawatan Jiwa, 1(2), pp.107-120. Available at: portalgaruda.org/?ref=browse \& $\mathrm{mod}=$ view issue\&journal=5090 Vol 1, No 2 (2013): Jurnal Keperawatan Jiwa.

Sadock, B. \& Sadock, V., 2010. Kaplan \& Sadock Buku Ajar Psikiatri Klinis, Jakarta: EGC.

Stuart, G. \& Laraia, 2005. Principles And Practice Of Psyhiatric Nursing, St Louis: Mosby Year B.

Surtiningsrum, A., 2011. Pengaruh terapi Suportif Terhadap Kemampuan Bersosialisasi Klien Isolasi Sosial di Rumah Sakit Jiwa Daerah Dr. Amino Gondohutomo Semarang. Universitas Indonesia.

Syarifuddin, 2012. Pendidikan dan Pemberdayaan Masyarakat, Medan: Perdana Publishing.

Videbeck, S., 2008. Buku Ajar Keperawatan Jiwa, Jakarta: EGC.

Wilkinson, J. \& Ahern, N., 2013. Buku Saku Diagnosis Keperawatan: Diagnosis NANDA Intervensi NIC Kriteria Hasil NOC, Jakarta: EGC.

Winarto, J., 2011. Teori Belajar Sosial Albert Bandura. Available at: http://edukasi.kompasiana.com/ 2011/03/12/teori-belajar-sosial-albertbandura-346947.html.

World Health Organization, 2014. Schizophrenia. Available at: http://www.who.int/mental_health/manag ement/ schizophrenia /en/\#. 